\title{
CHANGING PATTERNS OF THE PREVALENCE OF HELICOBACTER PYLORI AMONG PATIENTS AT A CORPORATE HOSPITAL IN GHANA
}

\author{
R. DARKO ${ }^{1}$, A. E. YAWSON ${ }^{2}$, V. OSEI ${ }^{3}$, J. OWUSU-ANSAH ${ }^{3}$ and S. ALUZE-ELE ${ }^{2}$ \\ ${ }^{1}$ Department of Surgery, University of Ghana School of Medicine and Dentistry, College of Health Sciences, \\ Korle-Bu, Accra, Ghana, ${ }^{2}$ Department of Community Health, School of Public Health, College of Health Sci- \\ ences. University of Ghana, Accra, Ghana, ${ }^{3}$ Cocoa Clinic, Accra, Ghana
}

DOI: $h$ ttp://dx.doi.org/10.4314/gmj.v49i3.4

Corresponding Author: Prof Rudolph Darko

E-mail: rudolphdarko@hotmail.com

Conflict of Interest: None declared

\section{SUMMARY}

Introduction: Helicobacter pylori (H. pylori) discovered in 1982, has strongly been associated with multiple clinical disorders of the gastrointestinal tract. This study described the prevalence of $H$. pylori among large numbers of patients over two different time periods in Accra, Ghana.

Methods: It was a retrospective records review on patients attending a quasi-government hospital in Accra, Ghana, during two time periods, 1999 and 2012. A total of 2401 records were reviewed, 1128 in first period and 1273 in second period. Biopsy was taken from the gastric antrum for Rapid Urease Test (RUT) in identifying H. Pylori. Data on patient characteristics, clinical diagnosis and findings upon endoscopy were analyzed by simple descriptive statistics. Associations between categorical outcome variables were determined by Chi square test at 95\% significance level.

Results: $H$. pylori infection was high in patients with upper gastrointestinal symptoms 69.7\% (1999) and $45.2 \%$ (2012), and was even higher in patients with gastritis and duodenal ulcer. H. pylori infection however, decreased among patients over the period, $69.7 \%$ in 1999 to $45.2 \%$ in 2012. Sex differences in $H$. pylori infection was identified (higher among males) and young adults (21-40 years). Commonest symptom in all patients was non-ulcer dyspepsia, 86.9\% in 1999 and $84.2 \%$ in 2012 , while gastritis and duodenal ulcer were the commonest endoscopic finding in the two periods.

Conclusion: Appropriate management guidelines in West Africa considering the high background $H$. pylori infection and other co-infections requiring particular antibiotic combination therapy is required.

Key words: Helicobacter pylori; endoscopy; prevalence; sex differences; Ghana

\section{INTRODUCTION}

The discovery of Helicobacter pylori (H. Pylori) in 1982 , to some, has changed the course of one of the more prolific lifestyle-altering diseases. ${ }^{1}$ It has strongly been associated with multiple clinical disorders (peptic ulcer disease, gastric adenocarcinoma and lymphoma and many other diseases of the gastrointestinal tract). ${ }^{1-}$ ${ }^{3}$ Those who consider H. Pylori as a major aetiologic factor in peptic ulcer disease follow H. pylori eradication protocols. Others still have resistance and sluggishness in accepting $\mathrm{H}$. Pylori as the cause of peptic ulcer disease. ${ }^{1-3}$ It is much more convincing if $\mathrm{H}$. Pylori are found to be associated with the disease in individuals.

H. pylori is said to be the most common gastrointestinal infection in man world-wide and causes different diseases in different persons. ${ }^{4}$ A large number of publications in Africans on H. Pylori are based on very few cases and therefore the conclusions drawn may not be representative. Guidelines for the management of $\mathrm{H}$. pylori have been developed in the Americas ${ }^{1}$, Europe ${ }^{5}$ and Asia Pacific. ${ }^{6}$ In the West African sub-region a number of acceptable diagnostic tests for infection are available. If endoscopy is to be performed, a biopsy urease test is recommended as the first test of choice, histology is recommended if the urease test is negative. $^{7}$

It is important to ascertain the prevalence of the disease in West Africa (as it is generally believed that the incidence of infection in the developing world is higher than that of the developed world) and to develop management guidelines of the disease in the sub-region. The aim of the study was to determine the prevalence of $H$. pylori in patients presenting with upper gastrointestinal symptoms referred for upper gastrointestinal endoscopy and to relate the presence or absence of $\mathrm{H}$. pylori to the various diseases found on upper gastrointestinal endoscopy. 
It described the pattern of prevalence of $\mathrm{H}$. pylori among a large number of male and female patients over two different time periods in Accra, Ghana.

\section{METHODS}

This was a retrospective review of health facility data undertaken at the Cocoa Clinic (a quasi-government health facility) in Accra, Ghana. It reviewed records on all clients attending the facility from two time periods, first period (1999) and second period (2012).

\section{Site of study}

The Cocoa clinic is located in the Okaikwei submetropolitan Assembly in Accra. The Clinic was established in 1973, to provide healthcare to staff and dependants of Cocobod (The cocoa marketing organization in Ghana). The clinic currently provides 24 hour services for staff of Cocoa Board and dependants, farmers, staff staff and dependents of corporate organizations and dependants, private individuals and the general public. Attendance is not limited to corporate clients. Daily average clinic attendance is 350 patients. The clinic operates the National Health Insurance Scheme (NHIS), as well as outof-pocket payment. Corporate clients access health care with specialized private insurance from their employers. The conditions requiring specialized care are referred mainly to the Korle- Bu Teaching Hospital and other tertiary health care facilities in Accra.

\section{Sampling Methods}

The study reviewed data on patients in 1999 and 2012, who under-went upper gastrointestinal (GI) endoscopy for various upper gastro-intestinal symptoms at the clinic. It was a total enumeration of routine service provision data at the clinic (those excluded from the analysis were those who had their endoscopy performed during the short periods that the RUT slide was unavailable for identification of $\mathrm{H}$. pylori). A total of 2401 outpatient records were reviewed 1128 patients during the first time period (1999) and 1273 patients in the second time period (2012). This two time periods were chosen because endoscopies were performed by the same consultant surgeon.

\section{Identification of $\mathrm{H}$. pylori}

In this study, H. Pylori was identified by the rapid urease test ('Pronto Dry'); manufactured by Gastrèx Sarl, 21640 Gilly Les Citeaux, France. Rapid urease tests (RUT) are simple biochemical tests, which involve placing an endoscopic biopsy specimen into a small amount of solution containing Urea, a $\mathrm{pH}$ indicator (phenol red) and a bacteriostatic agent. If $\mathrm{H}$. Pylori are present, the bacterial urease hydrolyses the urea and produces ammonia. Alkalinization of the medium produces a colour change from yellow to red. Results are read between one minute and 24 hours (the sensitivity and specificity of these methods are in the region of $95 \%$ ). ${ }^{8,9}$ At the clinic a biopsy was taken from the antrum for the RUT.

\section{Data collection}

An Abstraction form was used to collect data on patients from the medical record books. Data collected included demographic characteristics of clients, (such as age and sex of patients), date of endoscopy, main upper gastrointestinal symptoms or reasons for endoscopy, main findings upon endoscopy and the presence or absence of $H$. pylori.

\section{Data analysis}

Data from the abstraction form were entered into $\mathrm{Mi}$ crosoft Excel 2007 and imported into SPSS version 21, and analysed. Data were categorized by age (in 10 year age ranges, from $0-10,11-20,21-30$, and 31-40 up to $>$ 90 years). These age ranges were chosen to ensure that details of sex and age distribution of patients are available for analysis and also because of its practical usefulness in identifying at risk groups. Two main time periods, first period (1999) and second period (2012) were used for the analysis; to indicate possible changing patterns in the desired outcome measures.

Main outcome measures analysed for the study included, sex differences in patients undergoing endoscopy at the clinic, proportion of patients with particular upper gastrointestinal symptoms or reasons for upper GI endoscopy, main findings on endoscopy and the presence or absence of $H$. pylori in the antral biopsy. These outcomes were disaggregated by the two time periods. Endoscopic findings were classified in accordance with the World Health Organization's ICD-10 International classification of diseases. The upper GI symptoms of patients and endoscopic findings were ranked for each period. For this study, simple descriptive statistics such as frequencies, percentages, proportions and ratios were used for the analysis. Significant associations in categorical outcome measures were determined by Chisquare test at the $95 \%$ confidence level. p-values $<0.05$ were deemed significant.

\section{RESULTS}

As indicated in Table 1, there were 1120 (46.6\%) males and $1281(53.4 \%)$ females overall, given sex ratio $F$ : $M$ of 1:1.1 (median age for males was 38 and that for females was 37years). Majority of patients (both males and females) were in the age range 21-60 years. Only two patients were 10 years or less and only three were above 90 years old. There were more males in the first time period $(616 ; 55.2 \%$ vs. $512 ; 39.9 \%)$ whereas females were in the majority in the second time period $(772 ; 60.1 \%$ vs. $501 ; 44.8 \%)$. 
The sex differences in the two time periods was statistically significant $($ chi square $=56.9 ; \mathrm{p}$-value $=0.001$ )

Table 1 Age and sex characteristics of patients

\begin{tabular}{|c|c|c|c|}
\hline \multirow[b]{2}{*}{ Age group } & \multicolumn{2}{|c|}{ Sex of Patients } & \multirow[b]{2}{*}{ Total (\%) } \\
\hline & Male (\%) & $\begin{array}{l}\text { Female } \\
(\%)\end{array}$ & \\
\hline $0-10$ & $2(0.2)$ & 0 & $2(0.1)$ \\
\hline $11-20$ & $33(2.9)$ & $71(6)$ & $111(4.6)$ \\
\hline $21-30$ & $221(19.7)$ & $283(22.1)$ & $504(21)$ \\
\hline $31-40$ & $295(26.3)$ & $326(25.4)$ & $621(25.8)$ \\
\hline $41-50$ & $278(24.8)$ & $254(19.8)$ & $532(22.1)$ \\
\hline $51-60$ & $153(13.7)$ & $198(15.4)$ & $351(14.6)$ \\
\hline $61-70$ & $92(8.2)$ & $97(15.4)$ & $189(7.9)$ \\
\hline $71-80$ & $36(3.2)$ & $33(2.8)$ & $69(3)$ \\
\hline $81-90$ & $10(0.9)$ & $9(0.7)$ & $19(0.8)$ \\
\hline$>90$ & 0 & $3(0.2)$ & $3(0.2)$ \\
\hline Total & $1120(100)$ & $1281(100)$ & $2401(100)$ \\
\hline \multicolumn{4}{|l|}{ Time periods* } \\
\hline $\begin{array}{l}\text { First time period } \\
(1999)\end{array}$ & $616(55.2)$ & $512(39.9)$ & $1128(47)$ \\
\hline $\begin{array}{l}\text { Second time period } \\
(2012)\end{array}$ & $501(44.8)$ & $772(60.1)$ & $1273(53)$ \\
\hline Total & $1117(100)$ & $1284(100)$ & $2401(100)$ \\
\hline
\end{tabular}

"The sex differences in the two time periods was statistically significant $($ chi square $=56.9 ; p$-value $=0.001)$

Ranking of symptoms or reason for endoscopy over the two time periods as shown in Table 2, indicates the commonest upper gastro-intestinal symptom among patients who under-went endoscopy during the two periods was dyspepsia. This symptom constituted 980 $(86.9 \%)$ of all symptoms reported in the first time period (1999) and $1072(84.2 \%)$ in the second time period (2012). There were clear differences in the proportion of the other symptoms, for example epigastric pain was the second commonest symptom in the first period 58 $(5.1 \%)$ while no symptom of epigastric pain was recorded in the second time period.

Esophageal reflux was the second most common symptom reported in the second period $126(9.9 \%)$ while none was reported in the first period. Thus relatively more patients reported esophageal reflux and melaena stools in 2012 compared to 1999 , while relatively more patients reported epigastric pain and haematemesis in 1999. Single episodes of some other symptoms apart from those shown, constitute the other item in Table 2.

The top three endoscopic findings were similar over the two time periods as demonstrated in Table 3. These were normal findings, gastritis and duodenal ulcer. However, in 2012 Gastritis was the most common finding whilst normal findings were the commonest finding in 1999. Interestingly, close to three quarters 827
(73.3\%) of endoscopy revealed normal finding in 1999 while less than a third $387(30.4 \%)$ of endoscopic findings were normal in 2012.

Table 2 Main symptom or reason for endoscopy among patients in the two time periods (1999 and 2012)

\begin{tabular}{|c|c|c|c|c|}
\hline \multirow{3}{*}{$\begin{array}{l}\begin{array}{l}\text { Ranking } \\
\text { of symp- } \\
\text { toms }\end{array} \\
1\end{array}$} & \multicolumn{4}{|l|}{ Time period } \\
\hline & \multicolumn{2}{|c|}{$\begin{array}{lll}\text { First } & \text { time } & \text { period } \\
(1999) & & (\%)\end{array}$} & \multicolumn{2}{|c|}{$\begin{array}{l}\text { Second time period (2012) } \\
(\%)\end{array}$} \\
\hline & Dyspepsia & $\begin{array}{l}980 \\
(86.9)\end{array}$ & Dyspepsia & $\begin{array}{l}1072 \\
(84.2)\end{array}$ \\
\hline 2 & $\begin{array}{l}\text { Epigastric } \\
\text { Pain }\end{array}$ & $\begin{array}{l}58 \\
(5.1) \\
\end{array}$ & $\begin{array}{l}\text { Esophageal } \\
\text { Reflux }\end{array}$ & $\begin{array}{l}126 \\
(9.9)\end{array}$ \\
\hline 3 & Haematemesis & $\begin{array}{l}35 \\
(3.1) \\
\end{array}$ & $\begin{array}{l}\text { Melaena } \\
\text { Stools }\end{array}$ & $41(3.2)$ \\
\hline 4 & Belching & $\begin{array}{l}24 \\
(2.1)\end{array}$ & Vomiting & $13(1)$ \\
\hline 5 & Vomiting & $\begin{array}{l}17 \\
(1.5)\end{array}$ & $\begin{array}{l}\text { Gastric outlet } \\
\text { obstruction }\end{array}$ & $4(0.3)$ \\
\hline 6 & $\begin{array}{l}\text { Melaena } \\
\text { Stools }\end{array}$ & $\begin{array}{l}7 \\
(0.6) \\
\end{array}$ & Haematemesis & $1(0.1)$ \\
\hline 7 & $\begin{array}{l}\text { Retrosternal } \\
\text { Pain }\end{array}$ & $\begin{array}{l}5 \\
(0.4) \\
\end{array}$ & $\begin{array}{l}\text { Post Gastrec- } \\
\text { tomy }\end{array}$ & 0 \\
\hline 8 & $\begin{array}{l}\text { Epigastric } \\
\text { Mass }\end{array}$ & $\begin{array}{l}2 \\
(0.2) \\
\end{array}$ & $\begin{array}{l}\text { Epigastric } \\
\text { Pain }\end{array}$ & 0 \\
\hline 9 & $\begin{array}{l}\text { Post Gastrec- } \\
\text { tomy }\end{array}$ & $1(1)$ & $\begin{array}{l}\text { Retrosternal } \\
\text { Pain }\end{array}$ & 0 \\
\hline 10 & $\begin{array}{l}\text { Esophageal } \\
\text { Reflux }\end{array}$ & 0 & $\begin{array}{l}\text { Epigastric } \\
\text { Mass }\end{array}$ & 0 \\
\hline 11 & $\begin{array}{l}\text { Gastric outlet } \\
\text { obstruction }\end{array}$ & 0 & Belching & 0 \\
\hline 12 & Others & 0 & Others & $17(1.3)$ \\
\hline Total & & $\begin{array}{l}1128 \\
(100)\end{array}$ & & $\begin{array}{l}1273 \\
(100) \\
\end{array}$ \\
\hline
\end{tabular}

Table 3 Main Endoscopic findings in patients during the two time periods (1999 and 2012)

\begin{tabular}{|c|c|c|c|c|}
\hline \multirow{3}{*}{$\begin{array}{l}\text { Ranking of } \\
\text { endoscopic } \\
\text { findings }\end{array}$} & \multicolumn{4}{|l|}{ Time period } \\
\hline & \multicolumn{2}{|l|}{$\begin{array}{l}\text { First time period } \\
\text { (1999) }\end{array}$} & \multicolumn{2}{|l|}{$\begin{array}{l}\text { Second time period } \\
\text { (2012) }\end{array}$} \\
\hline & Normal findings & $827(73.3)$ & Gastritis & $639(50.2)$ \\
\hline 2 & Duodenal ulcer & $111(9.8)$ & Normal findings & $387(30.4)$ \\
\hline 3 & Gastritis & $91(8.1)$ & Duodenal ulcer & $222(17.4)$ \\
\hline 4 & Esophagitis & $33(2.9)$ & $\begin{array}{l}\text { Cancer of stom- } \\
\text { ach }\end{array}$ & $5(0.4)$ \\
\hline 5 & Duodenitis & $28(2.5)$ & $\begin{array}{l}\text { Prepyloric gastric } \\
\text { ulcer }\end{array}$ & $4(0.3)$ \\
\hline 6 & $\begin{array}{l}\text { Cancer of stom- } \\
\text { ach }\end{array}$ & $8(0.7)$ & Gastric polyp & $1(0.1)$ \\
\hline 7 & Gastric polyp & $7(0.6)$ & Duodenitis & $\mathbf{0}$ \\
\hline 8 & $\begin{array}{l}\text { Prepyloric gas- } \\
\text { tric ulcer }\end{array}$ & $2(0.2)$ & Esophagitis & $\mathbf{0}$ \\
\hline 9 & Others & $20(1.8)$ & 0thers & $15(1.2)$ \\
\hline Total & & $1128(100)$ & & $\begin{array}{l}1273 \\
(100)\end{array}$ \\
\hline
\end{tabular}


There were relatively more oesophagitis $33(2.9 \%)$ and duodenitis $28(2.5 \%)$ in the first time period compared to the second time period. Endoscopic findings involving more than one main finding, indicating differing combination of the main findings were represented as others in Table 3.

As illustrated in Table 4, the overall prevalence of $H$. pylori was higher in the first time period compared to the second $(69.7 \%$ vs. $45.2 \%$, this difference was statistically significant, p-value $<0.001$ ).

There were sex differences in the prevalence of $H$. $p y$ lori in the two time periods; in both periods, prevalence of $H$. pylori was higher among males than females. In 1999, H. pylori prevalence in males was $72.5 \%$ compared to females, $66.3 \%$. Similarly in 2012, H. pylori prevalence in males was $47.7 \%$ compared to females, $43.6 \%$.

Table 4 Prevalence of Helicobacter pylori by sex among patients in the two time periods

(1999 and 2012)

\begin{tabular}{|c|c|c|c|c|}
\hline \multirow[b]{2}{*}{$\begin{array}{l}\text { Sex of } \\
\text { patients }\end{array}$} & \multirow[b]{2}{*}{$\begin{array}{l}\text { Prevalence of } \\
\text { H pylori }\end{array}$} & \multicolumn{2}{|c|}{$\begin{array}{l}\text { Time period (prevalence } \\
\text { of } \mathrm{H} \text {. pylori) }\end{array}$} & \multirow[t]{2}{*}{$\begin{array}{l}\text { Total } \\
(\%)\end{array}$} \\
\hline & & $\begin{array}{l}\text { First time } \\
\text { period } \\
(1999) \\
(\%) \\
\end{array}$ & $\begin{array}{l}\text { Second } \\
\text { time peri- } \\
\text { od }(2012) \\
(\%)\end{array}$ & \\
\hline \multirow[t]{3}{*}{ Male } & positive & $447(72.5)$ & $239(47.7)$ & $686(61.4)$ \\
\hline & negative & $169(27.5)$ & $262(52.3)$ & $431(38.6)$ \\
\hline & Total & $616(100)$ & $501(100)$ & $1117(100)$ \\
\hline \multirow[t]{3}{*}{ Female } & positive & $339(66.3)$ & $337(43.6)$ & $675(52.6)$ \\
\hline & negative & $173(33.7)$ & $435(56.4)$ & $609(47.4)$ \\
\hline & Total & $512(100)$ & $772(100)$ & $1284(100)$ \\
\hline \multirow[t]{3}{*}{ Total } & positive & $786(69.7)$ & $575(45.2)$ & $1361(56.7)$ \\
\hline & negative & $342(30.3)$ & $698(54.8)$ & $1040(43.3)$ \\
\hline & Total & $1128(100)$ & $1273(100)$ & $2401(100)$ \\
\hline
\end{tabular}

Prevalence of $H$. pylori in the two time periods indicates higher prevalence among those aged 21- 50 years, as shown in Table 5.

In 1999, prevalence was highest among persons 31-40 years $(30 \%)$ followed by those $41-50$ years $(25 \%)$. In 2012, highest prevalence was in those 21-30 years (25.8\%) followed by those $31-40$ years $(22.4 \%)$.

The highest prevalence of $\mathrm{H}$. pylori decreased from 3140 years in 1999 to $21-30$ years in 2012. Only two patients were 10 years or less and only three were above 90 years old; H. pylori was detected in only one of those above 90 years.
Table 5 Prevalence of Helicobacter pylori by age groups among patients during the two time periods (1999 and 2012)

\begin{tabular}{|l|l|l|}
\hline \multirow{2}{*}{$\begin{array}{l}\text { Age group } \\
\text { (years) }\end{array}$} & $\begin{array}{l}\text { First time period } \\
(1999)\end{array}$ & $\begin{array}{l}\text { Second time } \\
\text { period } \\
(2012)\end{array}$ \\
\cline { 2 - 3 } $0-10$ & 0 & 0 \\
\hline $11-20$ & $30(3.6)$ & $37(6.4)$ \\
\hline $21-30$ & $134(17.1)$ & $143(25.8)$ \\
\hline $31-40$ & $232(30)$ & $123(22.4)$ \\
\hline $41-50$ & $198(25.5)$ & $103(18.3)$ \\
\hline $51-60$ & $106(13.4)$ & $83(14.6)$ \\
\hline $61-70$ & $71(8.8)$ & $42(7.5)$ \\
\hline $71-80$ & $14(1.4)$ & $23(3.9)$ \\
\hline $81-90$ & 0 & $7(1.2)$ \\
\hline$>90$ & $1(0.1)$ & 0 \\
\hline Total & $786(100)$ & $575(100)$ \\
\hline
\end{tabular}

\section{DISCUSSION}

Helicobacter pylori is one of the most common infections globally. It is now said to be the most common cause of peptic ulcer disease and gastric cancers ${ }^{10}$. This survey described the changing patterns in $H$. pylori among patients in a corporate hospital in Ghana during two different time periods (over a decade apart), and found that prevalence of $H$. pylori decreased over the period; from $69.7 \%$ in 1999 to $45.2 \%$ in 2012 .

Potential explanation for this finding may be the increasing effective measures at eradication of the infection with antibiotic combination therapy and also the widespread and indiscriminate use of antibiotics. It may also be related to the slightly improved awareness of sanitation among the inhabitants, for instance the introduction of 'sachet water' i.e. vended water being used in Ghana currently. ${ }^{11}$

Given the importance of eradicating $H$. pylori infection in patients with peptic ulcer disease, it is vital that infection is treated optimally with a combination regime that has an acceptable high eradication rate in the region of $90 \%$. Additional important factors to be taken into account when planning treatment include compliance and likelihood of adverse effects.

Despite the decrease in prevalence of $H$. pylori among patients in this review, the current prevalence of $45.2 \%$ is still high compared to rates in developed countries. ${ }^{10}$ 
The prevalence of $H$. pylori in the general population may be related to prevalence in symptomatic patients particularly those in whom no disease was found at endoscopy. The route of transmission of the disease may be faeco-oral and may explain the higher prevalence in developing countries due to low socioeconomic status, such as poor water supply, low refrigeration of food and low indoor plumbing. ${ }^{12}$ Other possible reasons for the high prevalence in developing countries may be due to vector transmission (such as the role of housefly). ${ }^{13}$

Overall, there were relatively more females referred for upper gastrointestinal tract endoscopy compared to males. There were significantly more males in the first time period compared to females, whereas females were in the majority in the second time period. Potential explanation for this finding may be that, in the first time period (1999) when there was no health insurance in Ghana, those who could afford services were the ones who visited the health facility; hence more males. In the second period (2012) with the availability of health insurance, the general health care utilization pattern at the population level where more females utilise health services than males in Ghana was demonstrated. $^{11,14}$

Sex differences existed in prevalence of $\mathrm{H}$. Pylori in the two time periods; in both periods, prevalence was higher among males than females. A study by Klein et al, in 1994 among 105 children in Peru showed boys were more significantly likely to acquire the infection and less likely to lose it. ${ }^{14} H$. pylori infection persists for many years once it is acquired, perhaps for life if not treated ${ }^{15}$. This may explain the persistently high prevalence of $H$. pylori among all the patients in this study; $69.7 \%$ in 1999 and $45.2 \%$ in 2012.

The host immune and inflammatory response is emerging as an important element in the pathogenesis of gastric diseases related to $H$. pylori. The presence of $\mathrm{H}$. pylori stimulates local and systemic immune responses and alters acid secretion, thereby causing gastric inflammation. The expression of $H$. pylori genes have been postulated as microbial factors influencing specific host clinical outcome because the genes are more frequently detected in isolates obtained from patients with peptic ulcer and those with gastric cancer. ${ }^{16,17}$ These host and agent factors may relate to the sex differences observed; molecular genetic studies may explain this sex difference in H. Pylori infection.

In concert with other enteric pathogens, childhood represents the phase of maximum susceptibility to infection with $H$. pylori. $^{18,19}$ It was shown among 105 children in Peru that the organism was present in $71.4 \%$ at
6 months and prevalence decreased to $47.9 \%$ at 18 months. ${ }^{15}$ Little however is known about the minimum infectious dose at any age. ${ }^{18,19}$ Our review demonstrates that the prevalence of $H$. pylori was highest among those aged between 21 and 50 years, the 31-40 year group had the highest prevalence in the first period whilst prevalence was highest among 21-30 year group over a decade later. Evidence exists to show that H. pylori infection persists for many years, perhaps for life once it is acquire ${ }^{15}$ and thus it is not surprising to see high prevalence of the infection in young adults.

Analysis of the main symptoms in patients that necessitated the conduct of upper gastrointestinal endoscopy demonstrated the commonest symptom among patients to be dyspepsia. This symptom constituted $87 \%$ of all symptoms reported by patients in 1999 and $84 \%$ in 2012. H. pylori has been found in $39-87 \%$ of patients with non-ulcer dyspepsia according to earlier studies. $^{20,21}$ In a similar study on the prevalence of H. pylori test done in Ibadan, Nigeria among 86 patients using rapid urease test, the most common finding was gastritis. ${ }^{22}$ However in another study in Ilorin, Nigeria among 125 patients with dyspepsia, 93.5\% were positive on serology while $80.0 \%$ was found on histology. ${ }^{23}$

H. Pylori infection of the gastric mucosa causes an active chronic gastritis, which in some cases progresses to multifocal atrophic gastritis. ${ }^{24}$ Surface gastric epithelial cell injury is a characteristic feature of this gastritis. $^{24}$ In vitro studies have shown that $H$. pylori, by direct contact and the elaboration of enzymes and putative cytotoxins, can directly injure cells and may therefore be responsible for the majority of gastric cell damage found in infected persons. ${ }^{24}$ Lipase and protease elaborated by $H$ pylori can degrade gastric mucus, shown by the loss of protective qualities of mucus. ${ }^{25}$

The urease of $H$. pylori is unique among bacterial ureases and helps protect the bacteria from acid by the production of ammonia, which increases the $\mathrm{pH}$ in the microenvironment around the organism. Direct injury to gastric epithelial cells occurs in vitro from ammonia $^{16}$. In addition, it has been shown that exposure of bacterial proteins and whole bacteria to gastric epithelial cells inhibit proliferation of gastric epithelial cells. ${ }^{17}$

Apart from dyspepsia being the common symptom over the two time periods, clear differences existed in the proportion of other symptoms. Strain differences in H. pylori have been postulated to account for different disease outcomes and symptoms found in persons infected with this bacterium. ${ }^{26}$ Clinical improvement in the symptoms has been shown after complete eradication of H. pylori. ${ }^{20,21}$ 
The commonest endoscopic findings among patients were gastritis, duodenal ulcer and those among whom no pathology was found (normal findings). Gastritis was the most common finding in 2012; however most patients in the 1999 group had normal findings on endoscopy. The pattern may probably be due to improved endoscopic techniques in identifying upper gastrointestinal pathology or improve methods in clinical diagnosis over the decade, such that most of those referred for endoscopy indeed showed some upper gastrointestinal pathology.

It is important to note that this review lacked historical information on the use of proton pump inhibitors (PPIs) in patients. Proton pump inhibitors may modify endoscopic diagnoses in patients and their use by patients (especially two weeks prior to endoscopy) may reduce the sensitivity of urease tests on gastric antral biopsy. In addition information on the use of nonsteroidal anti-inflammatory drugs (NSAIDS) in patients is important given its associated gastro-duodenal disease burden especially in H. pylori infected patients. The findings on endoscopy in this review should therefore be interpreted within this context.

Since the discovery of $H$. pylori in 1982, it has strongly been associated with multiple clinical disorders (peptic ulcer disease, gastric adenocarcinoma and lymphoma and many other diseases of the gastrointestinal tract $)^{1}$. It is therefore not surprising that multiple upper gastrointestinal conditions associated with $\mathrm{H}$. Pylori were demonstrated in this review (Table 3). The general pattern of endoscopic findings has not changed much among the patients over the two time periods

\section{Limitation}

The study was limited to two time periods (1999 and 2012), and was among symptomatic clients reporting to a corporate health facility and may not reflect the pattern in the general population. The two periods were chosen to compare changing patterns over a decade apart since the same consultant surgeon conducted the endoscopies in the chosen periods. Though a corporate health facility, outpatient services are opened to the general public.

Data including education, ethnicity, household characteristics and whether patients were on proton-pump inhibitors during endoscopy or had taken non-steroidal anti-inflammatory drugs would have provided useful information but were unavailable for this retrospective review. In addition only one test, (Rapid Urease Test, RUT) was used to determine H. Pylori; the authors acknowledge the limitations of RUT and a potential false negative or false positive outcomes. $8,9,16,17$

\section{CONCLUSION AND RECOMMENDA- TIONS}

The re-discovery of $H$. pylori is one of the most important developments in the past millennium. In this review the prevalence of $\mathrm{H}$. pylori infection was quite high (in patients with upper gastrointestinal symptoms and even higher in patients with gastritis and duodenal ulcer). It was relatively higher among males and young adults (21-40 years). Prevalence of $H$. pylori however, decreased among patients from $70 \%$ in 1999 to $45 \%$ in 2012. The most common symptom among patients was non-ulcer dyspepsia, while the commonest endoscopic findings were gastritis, duodenal ulcer and those with no detectable pathology.

Today there is no longer any serious debate about the value of appropriateness of treatment of upper gastrointestinal conditions such as duodenal ulcer by elimination of H. pylori. This is based on overwhelming evidence from clinical trials reinforced by several years of clinical practice.

It is important to develop appropriate guidelines in West Africa, taking into consideration the high background prevalence of this infection and the high prevalence of other infections, which may require particular antibiotic combination therapy. Another group of patients who need consideration are the non-ulcer dyspeptic patients who are infected with $H$. pylori.

Currently one of the most important unresolved clinical questions about H. Pylori is whether cure of the infection leads to a sustained improvement of the non-ulcer dyspeptic symptoms. Should we attempt to eliminate the $H$. pylori in these patients especially in those patients who continue to lose valuable working time because of continuing non-ulcer dyspepsia? More work needs to be done in this subject area.

\section{ACKNOWLEDGEMENT}

We are most grateful to all the health and support staff of the Cocoa Clinic in Accra where the study was conducted and to all the patients whose records were used for the survey. We are thankful to the management of the Cocoa Clinic for the support provided for the survey. RD and VO developed the concept and planned the study. Data was collected by RD, VO and J O-A. Data was analyzed and interpreted by AEY and A-E S. The first draft of the manuscript was produced by RD and AEY. VO, J O-A and A-E S contributed to the writing and edited of different portions of the manuscript. All authors read and approved the final draft manuscript before submission. 


\section{REFERENCES}

1. Howden CW, Hunt RH. Guidelines for the management of infection. The Am J Gastroenterol 1998; 93:2330-2338

2. Warren JR and Marshall BJ. Unidentified curved bacilli on gastric epithelium in active chronic gastritis. Lancet. 1983;1(8336):1273-1275

3. Genta RM, Yardley JH, Correa P. Classification and grading of gastritis: The updated Sydney system. International workshop on the Histopathology of gastritis, Houston in 1994. Am J Surg Histopathol. 1996; 20:1161-1181

4. Gasbarrini G, Malfertheimer P, Delternre $M$. New concepts concerning management of Helicobacter pylori infection: 2 years after the Maastricht Consensus Report. Ital J Gastroenterol Hepatol. 1998;30(3):1-4

5. The European Helicobacter pylori study Group . Currents European concepts in the management of Helicobacter pylori infection. The Maastricht Consensus Report Gut. 1997; 41:8-13

6. Lam SK and Yalley NJ. Helicobacter consensus. Report of the 1997 Asia Pacific Consensus Conference on the management of Helicobater pylori infection. Journal of Gastroenterology and Hepatology. 1998;13:1-12.

7. Stenström B, Mendis A, Marshall B. "Helicobacter pylori-The latest in diagnosis and treatment". Aust Fam Physician. 2008; 37(8): 608-612.

8. Mobley HLT, Cortesia MJ, Rosenthal LE . Characterization of urease from Campylobacter pylori. J Clin Microbiol. 1998; 26:831-836.

9. $\mathrm{Hu}$ LT, Mobley HLT. Purification and N-terminal analysis of urease from Helicobacter pylori. Infect Immun. 1990;58:992-998

10. Barclay L and Lie D. Guidelines for Treatment of Helicobacter pylori Infection, American College of Gastroenterology, August 2007.

11. Ghana Health Service (GHS) Annual Report, 2012. Report Published by Ghana Health Service in 2013.

12. Graham DY, Malaty HM, Evans DJ . Epidemiology of Helicobacter pylori in a symptomatic population in the United States. Gastroenterology. 1991;100:1495-1501

13. Grubel P, Hoffman JS, Burstein NA . Vector potential of houseflies (Musca domestica) for Heli- cobacter pylori. J Helicobactor pylori. Clin $\mathrm{Mi}$ crobiol. 1997;35:1300-1303

14. Ghana National Health Insurance Act 650 of the Republic of Ghana, August, 2003. Published by the Ghana Assembly Press, Accra, Ghana, 2003.

15. Klein PD, Gilman RH, Leon-Barua R. The epidemiology of Helicobacter pylori in Peruvian children between 6 months and 30 months of age. Am Gastroenterol. 1994;89:2196-2200

16. Smoot DT, Mobley HLT, Lewison JF . Helicobacter pylori urease activity is toxic to human gastric epithelial cells. Infect immune. 1990;58:1992-1994

17. Knip U, Birkholz S, Wolfgang K . Partial characterization of a cell proliferation-inhibiting protein produced by helicobacter pylori. Infect Immun.1996;64:3491-3496

18. Marshall BJ, Armstrong JA, McGechie DB . Attempt to fulfil Kock's postulates for pyloric Campylobacter. Med J Aust.1985;142:436-439

19. Morris A and Nicholson G. Ingestion of Campylobacter pyloridis causes gastritis and raised fasting pH. Am Gastrenterol. 1987;82:192-199

20. Kuipers EJ, Uytelinde AM, Pena AS . Long-term sequelae Helicobacter gastritis. Lancet. 1995; 345:1525-1528

21. Wyatt JL. Histopathology of gastroduodenal inflammation: the impact of Helicobacter pylori. Histopathology. 1995;26:1-15

22. Jemilohun AC, Otegbayo JA, Ola SO, Oluwasola OA, Akere A. Prevalence of helicobacter pylori among Nigerian patients with dyspepsia in Ibadan. Pan African Medical Journal. 2011; 6:18. http://www.panafrican-medjournal.com/content/article/6/18/full/

23. Olokoba AB, Gashau W, Bwala S, Adamu A and Salawu FK. Helicobacter Pylori Infection In Nigerians With Dyspepsia. Ghana Medical Journal 2013; 47(2): 79-81

24. Dixon MF. Pathophysiology of Helicobacter pylori infection. Scand Gastroenterol. 1994;201:7-10

25. Slomainy BL and Slomainy A. Mechanism of Helicobacter pylori focus on mucus. J Clin Gastroenterol. 1992;14(11):114-121

26. Blaser MJ. Helicobacter pylori phenotypes associated with peptic ulceration. Scand Gastroenterol 1994;29(205):1-5 